\title{
Public Services Efficiency Provision in Italian Regions: a Non-Parametric Analysis \#
}

\author{
António Afonso * and Carla Scaglioni ${ }^{* *}$
}

February 2005

\begin{abstract}
We measure the performance of public spending in Italian regions regarding the provision of public services, by constructing a so-called total regional performance indicator for strategic sectors such as general administration, energy, water and sewage, solid waste, and transports for 2001. This composite indicator is then the output measure selected to assess expenditure efficiency for the Italian regions, using the non-parametric DEA approach. The computation of efficiency scores allows to rank the regions and to detect some room for improvement in terms of efficiency gains at the regional level.
\end{abstract}

JEL Classification Numbers: C14, H42, H72, R50

Keywords: technical efficiency, DEA, regional expenditure, Italy

\footnotetext{
\# We thank Assunta Draicchio and Emma Galli for helpful comments, and MEF-DPS, Banca Dati Conti Pubblici Territoriali, for providing the data on regional expenditure. The opinions expressed herein are those of the authors and do not necessarily reflect those of the author's employers.

${ }^{*}$ ISEG/UTL - Technical University of Lisbon, Department of Economics, and CISEP - Research Centre on the Portuguese Economy, R. Miguel Lúpi 20, 1249-078 Lisbon, Portugal, email: aafonso@iseg.utl.pt.

** University of Rome "Roma Tre" and CIFREL - Centro Interuniversitario di Finanza Regionale e Locale - Università Cattolica di Milano, Italy, email: carla.scaglioni@tesoro.it.
} 


\section{Contents}

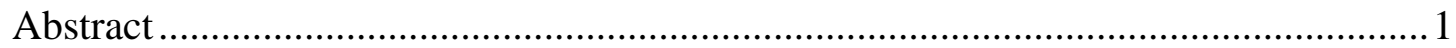

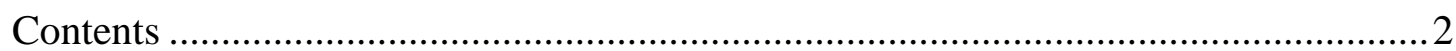

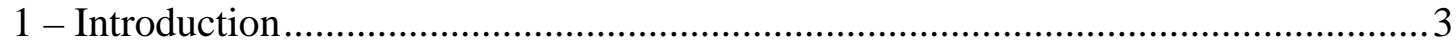

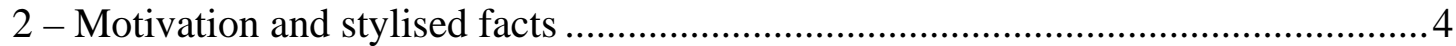

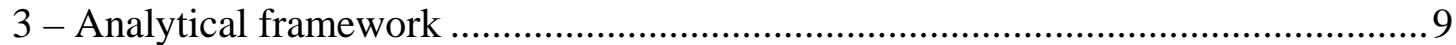

4 - Non-parametric efficiency analysis of regional spending in Italy ........................11

4.1 - Total regional performance indicator (TRPI) ................................................ 12

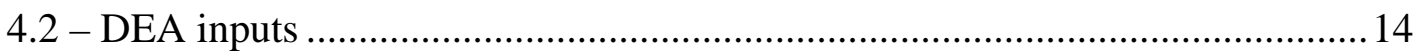

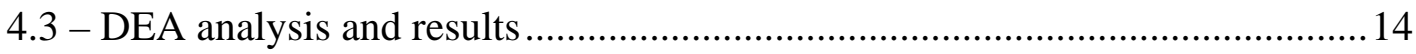

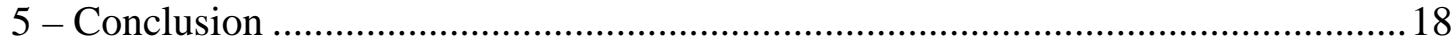

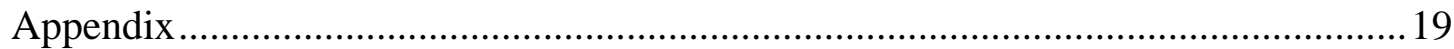

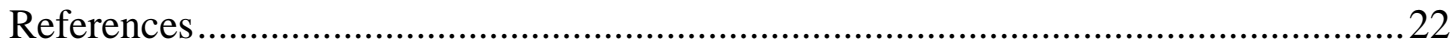

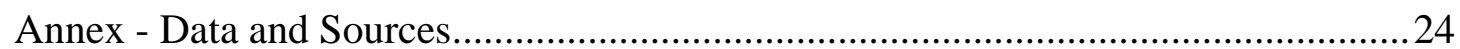




\section{1 - Introduction}

Some available studies assess the performance and efficiency of public sector spending, namely in terms of international comparisons. For instance, Fakin and Crombrugghe (1997) and Afonso, Schuknecht and Tanzi (2003) assess public expenditure in the OECD, Clements (2002) analysis education spending in Europe, Gupta and Verhoeven (2001) addresses education and health in Africa, while St. Aubyn (2003) and Afonso and St. Aubyn (2004) study health and education expenditure efficiency in the OECD. Nevertheless, the literature on the efficiency of local government is rather scarce. De Borger and Kerstens (1996) apply nonparametric analysis to public spending efficiency in Belgian municipalities, while Afonso e Fernandes (2003) also use a non-parametric approach for municipalities in the region of Lisbon, and Balassone, Francese and Giordano (2002) review nonparametric applications to some public services in Italy.

The purpose of this paper is to assess the efficiency of publicly provided private services at the regional level in Italy. We measure the performance of Italian regions regarding the provision of public services by constructing a so-called total regional performance indicator for strategic sectors such as general administration, energy, water and sewage, solid waste, transports. Using such composite indicator as an output measure, we then use a non-parametric methodology, Data Envelopment Analysis (DEA), to estimate efficiency scores for public spending in the 20 Italian Regions in 2001. By means of frontier analysis we are able to identify regions that might qualify as "performing well" from those were some improvement might increase their efficiency. To our knowledge, this is a first effort of checking efficiency and productivity in Italian Regions using non-parametric analysis. Moreover, the relationship between citizens and policy makers as far as the demand for efficient public services is concerned will also be discussed.

The paper is organised as follows. In section two we give some motivation and provide stylised facts regarding the Italian Regions. Section three briefly presents the analytical framework. In section four we compute a regional performance indicator, which is then used as the output measures in the DEA analysis whose results are then reported and discussed. Section five provides conclusions. 


\section{2 - Motivation and stylised facts}

Italy has devoted the last decade to "reform" the public governance, shifting from a highly interventionist state towards a modern regulatory one, introducing transparent rules, market openness, and competition. According to the Regulator's aim, the reform should have been able to enforce the competition, but the reality was very complex, showing the presence of significant diversity among the Italian regions. In some cases, there was a bias either in granting long concessions or to maintain the direct control on the service delivery. Nevertheless, in other cases, there was openness towards a more competitive market, introducing the tender system. Consequently, as more powers have been delivered to regional and local governments, the task of monitoring and correcting competition problems in regulation has become more complex, highlighting the absence of a well-established culture of competition in local governments.

The Italian utilities and network industries have changed significantly during the last ten years. This process was due namely to the response that Italy gave to European obligations to liberalise the public utilities sectors, in line to what happended across the euro area. Consequently, Italy’s governance and markets were reformed and new relations established between the State, citizens, and the market. In order to assess the performance and responsibilities of the Italian regions in providing public services, a brief overview of the local government institutional features and responsibilities is provided below.

Still far of being a federal state, Italy is nowadays a regional state, whose local government is organised in three subnational levels as shown in Figure 1. 
Figure 1 - The organization of the local government in Italy

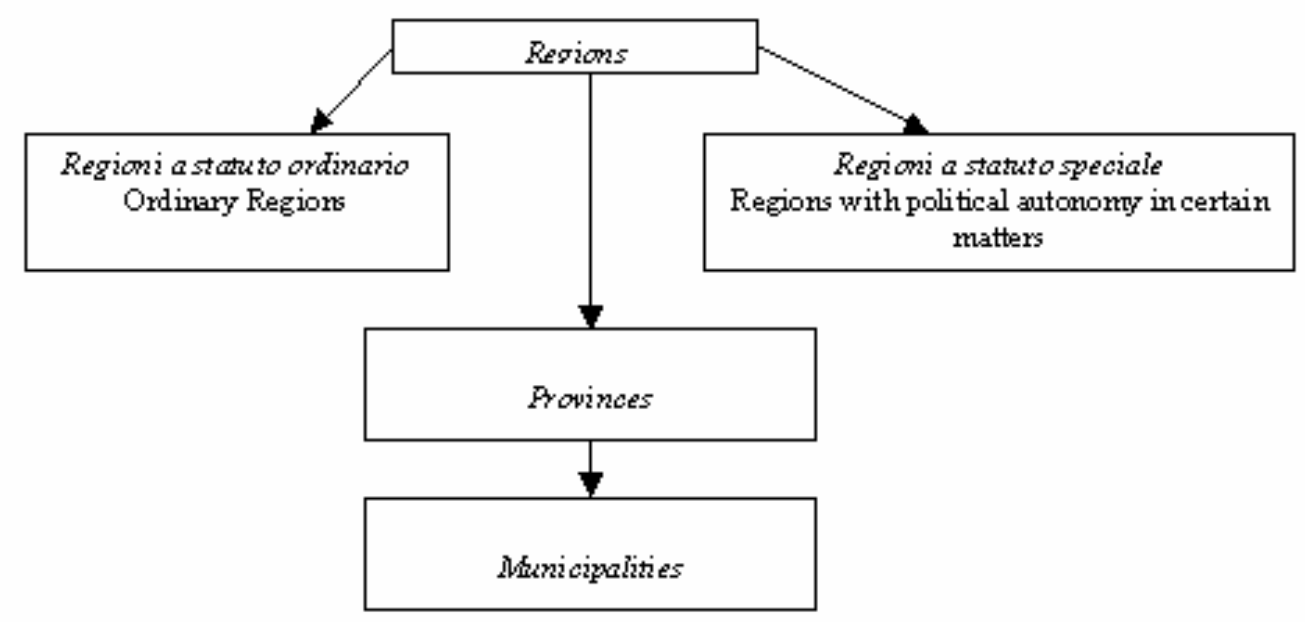

Note: Ordinary regions (Abruzzo, Basilicata, Calabria, Campania, Emilia - Romagna, Lazio, Liguria, Lombardia, Marche, Molise, Piemonte, Puglia, Toscana, Umbria, Veneto); regions with relative political autonomy (Valle d'Aosta, Trentino Alto Adige, Sicilia, Sardegna and Friuli Venezia Giulia).

The first level includes the 20 Italian regions, which are divided in Ordinary Regions (regioni a statuto ordinario) and regions with political autonomy in certain matters (regioni a statuto speciale). While the latter (Valle d'Aosta, Trentino Alto Adige, Sicilia, Sardegna and Friuli Venezia Giulia) were formally established between 1943 and 1963, the former were only created in 1970. The choice of the distinction was due mainly to the pressing demand of authonomy according to the peculiar etnical culture of those regions. Despite this regional organisation being in place for more than twenty years, the country was characterised by a highly centralised model, where the others local entities at the second level, Provinces and Municipalities had only a residual power.

Since 1997, after the introduction of the so-called "Bassanini reforms", a significant programme for public sector revitalisation helped the country in improving its use of best practice tools for regulatory quality. Legislation identifying the specific tasks of the regions and of the other local entities was introduced in order to guarantee the socalled territorial empowerment, reinforcing the effectiveness of the local policies. ${ }^{1}$ Moreover, the Constitutional Reform that occurred in 2000, has modified

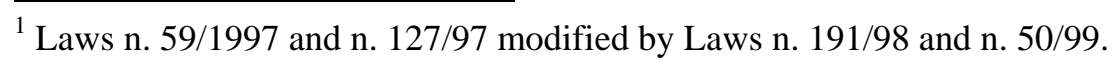


substantially the regions' competences giving them new powers. ${ }^{2}$ In particular, two main innovations should be mentioned:

i) The range of competencies on which regions can legislate was fully modified, i.e. the law mentions that the regions have the legislative power on all the topics not expressly reserved to the national government; ${ }^{3}$

ii) A series of exclusive competences are attributed to the regions, on which the national government has no longer power.

As shown in Table 1, regions have de facto implemented their local power, both on the provision of public goods and on the definition of the local regulatory system. ${ }^{4}$

\section{Table 1 - Main areas on which the Italian regions have both legislative and administrative competence}

\begin{tabular}{lll}
\hline \multicolumn{1}{c}{ Social Services } & \multicolumn{1}{c}{$\begin{array}{c}\text { Planning and use of the } \\
\text { territory }\end{array}$} & \multicolumn{1}{c}{$\begin{array}{c}\text { Government of } \\
\text { Economics }\end{array}$} \\
\hline - Health care system & - Urban and territorial & - Tourisme \\
- School sid & planning & - Commerce \\
- Cultural supply & - Water and sewage system & - Agriculture \\
- Professional training & - Defence of the territory & - Fishery \\
- Social sid & - Protection of the & - Handicrafts \\
- Welfare assistance & $\begin{array}{l}\text { environment } \\
\text { - Transport planning with }\end{array}$ \\
& the possibility to give & \\
& transfer funds in order to & \\
& help local inefficient public & \\
& companies & \\
\hline
\end{tabular}

Source: Scaglioni (2004).

During the last decade a variety of incentives, such as service contracts (Contratti di servizio) and citizens charts (Carte dei Servizi) for public services were introduced in order to improve the quality of the public services (transports, sanity, energy, communications), and to provide commitments to performance criteria and compensation for customer non-satisfaction. Moreover, an effort was made to liberalise local public utilities, with the attempt to introduce market principles in water

\footnotetext{
${ }^{2}$ Constitutional Law n. 3/2001.

3 This broadens the number of competences that can be regulated by the regional autorities. For an historical excursus, see Giarda (2004).

${ }^{4}$ In the Appendix, more detailde information is provided concerning the main interventions that occurred in some public utilities sectors.
} 
distribution, energy (other than electricity), public transport, and waste management, and a series of laws were approved to change the regulatory framework. ${ }^{5}$

Alongside with the aforementioned institutional reforms, it was possible to notice the increase of both investment and employment levels in local public services. For instance, investment in total public services increased significantly in Italy between 1998 and 2002, around 33.9 per cent, while investment in local public services increased even more, by 43.3 per cent (see Figure 2). Additionally, and considering the variation of employment, Figure 3 shows that employment in local public services broadly stabilised in the same period, vis-à-vis a decrease of some 10 per cent in total public services.

Figure 2 - Investment developments (1998-2002)

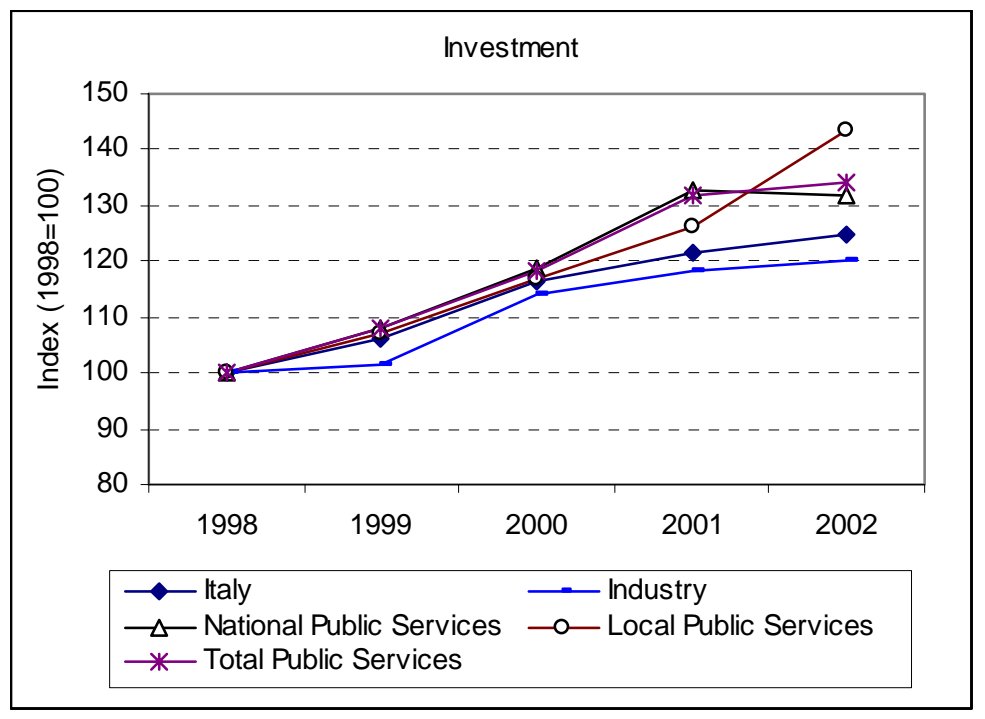

Source: adapted from Confservizi (2004).

\footnotetext{
${ }^{5}$ In the Appendix we provide an illustration of the key regulatory interventions occurred in the sectors we are considering.
} 
Figure 3 - Employment developments (1998-2002)

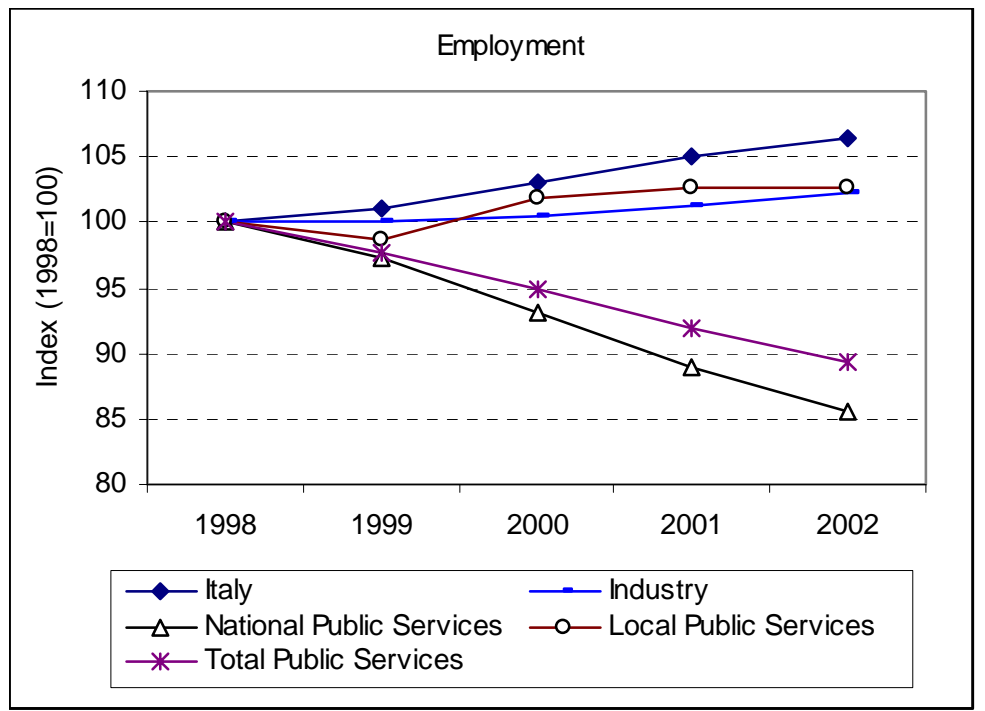

Source: adapted from Confservizi (2004)

The objective of the reforms was to promote competition, even if its effectiveness depended mainly on the support given by the local governments. In practice, the results were mixed across the Italian regions. In some cases, there was a strong will to maintain the direct control of the service delivery, while there was also openness towards a more competitive market, introducing the tender system. ${ }^{6}$

As more powers have been devolved to regional and local governments, the task of monitoring and correcting regulatory competition problems has become more complex. This stems partly from the fact that the culture of competition is still not well established in local governments. Many concession-granting powers remain under local and regional governments' control including licensing, land use, and planning and development. One of the possible disadvantages of the reform was a potential for confusion between supervision and management, together with a long transition process, which may have weakened the force of competition or reinforced the pre-existent monopolies.

\footnotetext{
${ }^{6}$ As in the case of the local public transports in Rome and in Valle d'Aosta. For a review on local public transports, see Boitani and Cambini (2001).
} 


\section{3 - Analytical framework}

Data Envelopment Analysis, originating from Farrell (1957) seminal work and popularised by Charnes, Cooper and Rhodes (1978), assumes the existence of a convex production frontier, a hypothesis that is not required for instance in the Fred Disposable Hull approach. The production frontier in the DEA approach is constructed using linear programming methods. The terminology "envelopment" stems out from the fact that the production frontier envelops the set of observations. ${ }^{7}$

DEA allows the calculation of technical efficiency measures that can be either input or output oriented. The purpose of an input-oriented study is to evaluate by how much input quantity can be proportionally reduced without changing the output quantities. Alternatively, and by computing output-oriented measures, one could also try to assess how much output quantities can be proportionally increased without changing the input quantities used. The two measures provide the same results under constant returns to scale but give different values under variable returns to scale. Nevertheless, and since the computation uses linear programming, not subject to statistical problems such as simultaneous equation bias and specification errors, both output and inputoriented models will identify the same set of efficient/inefficient producers or Decision Making Units (DMUs). ${ }^{8}$

The analytical description of the linear programming problem to be solved, in the variable returns to scale hypothesis, is sketched below. Suppose there are $k$ inputs and $m$ outputs for $n$ DMUs. For the i-th DMU, $y_{i}$ is the column vector of the outputs and $x_{i}$ is the column vector of the inputs. We can also define $X$ as the $(k \times n)$ input matrix and $Y$ as the $(m \times n)$ output matrix. The DEA model is then specified with the following mathematical programming problem, for a given i-th DMU: ${ }^{9}$

\footnotetext{
${ }^{7}$ Coelli et al. (2002), and Thanassoulis (2001) offer good introductions to the DEA methodology.

${ }^{8}$ In fact, the choice between input and output orientations is not crucial since only the two measures associated with the inefficient units may be different between the two methodologies.

${ }^{9}$ We simply present here the equivalent envelopment form, derived by Charnes et al. (1978), using the duality property of the multiplier form of the original programming model.
} 


$$
\begin{array}{ll}
\text { MIN }_{\theta, \lambda} \theta & \\
\text { s. to } & -y_{i}+Y \lambda \geq 0 \\
& \theta x_{i}-X \lambda \geq 0 \\
& n 1^{\prime} \lambda=1 \\
& \lambda \geq 0
\end{array} .
$$

In problem (1), $\theta$ is a scalar (that satisfies $\theta \leq 1$ ), more specifically it is the efficiency score that measures technical efficiency of unit $\left(x_{i}, y_{i}\right)$. It measures the distance between a decision unit and the efficiency frontier, defined as a linear combination of best practice observations. With $\theta<1$, the decision unit is inside the frontier (i.e. it is inefficient), while $\theta=1$ implies that the decision unit is on the frontier (i.e. it is efficient).

The vector $\lambda$ is a $(n \times 1)$ vector of constants, which measures the weights used to compute the location of an inefficient DMU if it were to become efficient. The inefficient DMU would be projected on the production frontier as a linear combination, using those weights, of the peers of the inefficient DMU. The peers are other DMUs that are more efficient and therefore are used as references for the inefficient DMU.

$n 1$ is a n-dimensional vector of ones. The restriction $n 1^{\prime} \lambda=1$ imposes convexity of the frontier, accounting for variable returns to scale. Dropping this restriction would amount to admit that returns to scale were constant. Additionally, notice that problem (1) has to be solved for each of the $n$ DMUs in order to obtain the $n$ efficiency scores.

In a simple example, three different hypothetical regions display the following values for indicator $y$ and expense level $x$, as reported in Table 2:

Table 2 - Values for regions A, B and C

\begin{tabular}{lcc}
\hline & Indicator & Expenditure \\
\hline Region A & 65 & 800 \\
Region B & 68 & 1150 \\
Region C & 75 & 1000 \\
\hline
\end{tabular}


Expenditure is lower in region $\mathrm{A}$, and the output level is also the lowest. Region $\mathrm{C}$ does not exhibit the highest expenditure, and attains the best level of output. Region B may be considered inefficient, in the sense that it performs worse than region $\mathrm{C}$. The latter achieves a better status with less expense.

Figure 4 illustrates DEA frontiers with the data of Table 2. The variable returns to scale frontier unites the origin (not depicted) to point $\mathrm{A}$, and then point $\mathrm{A}$ to point $\mathrm{C}$.

\section{Figure 4 - DEA frontiers}

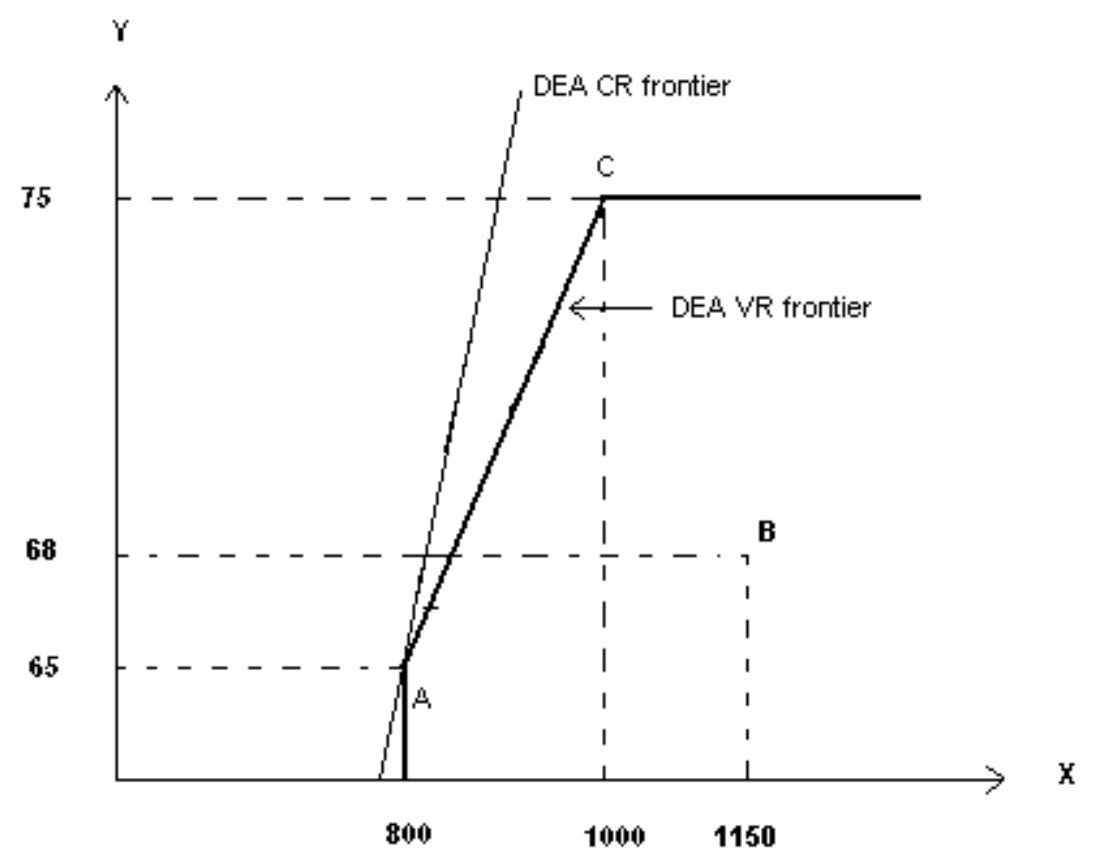

\section{4 - Non-parametric efficiency analysis of regional spending in Italy}

In our analysis we assess the efficiency for strategic sectors such as general administration, energy, water and sewage, solid waste, transports of the 20 Italian Regions in 2001. As inputs we use both public sector employees and public expenditure. Particularly, we use the database on Regional Public Accounts (MEFDPS, Banca Dati Conti Pubblici Territoriali) collected by the Italian Ministry for Economics and Finance. Regarding the output measure we first construct a composite indicator that tries to take into account the several areas of public provision of services and goods. 


\section{1 - Total regional performance indicator (TRPI)}

In this subsection we construct our measure of performance for Italian regions in providing public services to the population, by computing the so-called total regional performance indicator (TRPI) for 2001. This composite indicator is a simple average of seven sub-indicators of regional public performance: water provision, waste collection, frequency of the accidental long interruptions of the electrical service, public transportation utilization, railway utilization, motorway network, and houses provide with gas. ${ }^{10}$

We compile the performance indicator from the various indices giving equal weight to each of them. ${ }^{11}$ This weighing up of the variables is quite straightforward and economically intuitive (even though it is still somewhat ad hoc). It avoids the problem of lack of economic justification of a more complex statistical approach such as principal component analysis that might come to mind in this context.

For those indicators where higher numbers are less favourable (e.g., irregularity in water provision, frequency of the accidental long interruptions of the electricity provision), we use the inverse of the original values. In order to facilitate the compilation, we normalised the values and set the average for all indices equal to unity (following the methodology adopted by Afonso et al. (2003)). The values for each region are then recalculated relative to the average. Table 1 presents the results for the constructed TRPI indicator for the year 2001.

\footnotetext{
${ }^{10}$ The data and the respective sources are provide in the Annex.

${ }^{11}$ For example, water provision contributes $1 / 7$ per cent to the total regional performance indicator.
} 
Table 3. Total regional performance indicator (TRPI), 2001

(Sub-indicators are normalised to unity)

\begin{tabular}{|c|c|c|c|c|c|c|c|c|}
\hline Region & $\begin{array}{c}\text { Irregularity } \\
\text { in water } \\
\text { provision }\end{array}$ & $\begin{array}{c}\text { Waste } \\
\text { collection }\end{array}$ & $\begin{array}{l}\text { Electric } \\
\text { service } \\
\text { failures }\end{array}$ & $\begin{array}{c}\text { Public } \\
\text { transport } \\
\text { utilization } \\
\text { index }\end{array}$ & $\begin{array}{l}\text { Railway } \\
\text { utilization } \\
\text { index }\end{array}$ & $\begin{array}{c}\text { Motorway } \\
\text { network } \\
(\mathrm{km} / \\
\text { square } \mathrm{km})\end{array}$ & $\begin{array}{c}\text { Gas } \\
\text { (\% houses } \\
\text { provided) }\end{array}$ & $\begin{array}{c}\text { TRPI } \\
\text { (equal } \\
\text { weights } \\
1 / \text { ) }\end{array}$ \\
\hline Abruzzo & 0.43 & 1.04 & 0.90 & 1.09 & 0.62 & 0.92 & 1.14 & 0.88 \\
\hline Basilicata & 0.33 & 0.94 & 0.62 & 1.24 & 0.43 & 0.65 & 0.84 & 0.72 \\
\hline Calabria & 0.18 & 0.66 & 0.37 & 1.09 & 0.89 & 0.90 & 0.39 & 0.64 \\
\hline Campania & 0.49 & 0.86 & 0.61 & 1.29 & 1.43 & 1.01 & 0.92 & 0.94 \\
\hline Emilia - Romagna & 1.59 & 1.14 & 1.39 & 0.72 & 0.93 & 0.66 & 1.48 & 1.13 \\
\hline Friuli - Venezia Giulia & 4.22 & 0.92 & 1.72 & 0.82 & 0.85 & 0.61 & 1.30 & 1.49 \\
\hline Lazio & 0.67 & 1.00 & 0.73 & 1.45 & 1.60 & 0.77 & 1.41 & 1.09 \\
\hline Liguria & 1.77 & 1.01 & 1.23 & 1.48 & 2.83 & 0.69 & 1.24 & 1.46 \\
\hline Lombardia & 1.20 & 0.98 & 1.66 & 1.22 & 1.56 & 0.92 & 1.58 & 1.30 \\
\hline Marche & 0.96 & 0.97 & 1.23 & 0.78 & 0.41 & 1.69 & 1.22 & 1.04 \\
\hline Molise & 0.44 & 0.90 & 0.75 & 1.27 & 0.39 & 0.16 & 1.03 & 0.71 \\
\hline Piemonte & 1.25 & 0.95 & 1.14 & 0.98 & 1.40 & 3.13 & 1.35 & 1.46 \\
\hline Puglia & 0.31 & 0.89 & 0.83 & 0.86 & 1.07 & 3.51 & 0.97 & 1.21 \\
\hline Sardegna & 0.22 & 1.02 & 0.41 & 0.96 & 0.70 & 0.45 & 0.02 & 0.54 \\
\hline Sicilia & 0.24 & 0.75 & 0.52 & 0.80 & 0.40 & 1.13 & 0.49 & 0.62 \\
\hline Toscana & 0.82 & 1.28 & 0.91 & 0.78 & 1.04 & 0.63 & 1.39 & 0.98 \\
\hline Trentino - Alto Adige & 2.09 & 1.04 & 0.86 & 1.07 & 0.76 & 0.24 & 0.57 & 0.95 \\
\hline Umbria & 0.73 & 1.27 & 1.34 & 0.75 & 0.77 & 0.25 & 1.24 & 0.91 \\
\hline Valle D'Aosta & 1.00 & 1.23 & 1.68 & 0.52 & & 0.07 & 0.19 & 0.78 \\
\hline Veneto & 1.05 & 1.15 & 1.11 & 0.82 & 0.92 & 1.60 & 1.23 & 1.13 \\
\hline Average & 1.00 & 1.00 & 1.00 & 1.00 & 1.00 & 1.00 & 1.00 & 1.00 \\
\hline Maximum & $\begin{array}{c}4.22 \\
(\mathrm{FVG})\end{array}$ & $\begin{array}{c}1.28 \\
\text { (TOS) }\end{array}$ & $\begin{array}{c}1.72 \\
\text { (FVG) }\end{array}$ & $\begin{array}{c}1.48 \\
\text { (LIG) }\end{array}$ & $\begin{array}{c}2.83 \\
\text { (LIG) }\end{array}$ & $\begin{array}{c}3.51 \\
\text { (PUG) }\end{array}$ & $\begin{array}{c}1.58 \\
\text { (LOM) }\end{array}$ & $\begin{array}{c}1.49 \\
\text { (FVG) }\end{array}$ \\
\hline Minimum & $\begin{array}{c}0.18 \\
\text { (CAL) }\end{array}$ & $\begin{array}{c}0.66 \\
\text { (CAL) } \\
\end{array}$ & $\begin{array}{c}0.37 \\
(\mathrm{CAL})\end{array}$ & $\begin{array}{c}0.52 \\
\text { (VDA) } \\
\end{array}$ & $\begin{array}{c}0.39 \\
(\mathrm{MOL})\end{array}$ & $\begin{array}{c}0.07 \\
\text { (VDA) }\end{array}$ & $\begin{array}{c}0.02 \\
\text { (SAR) } \\
\end{array}$ & $\begin{array}{c}0.54 \\
\text { (SAR) }\end{array}$ \\
\hline
\end{tabular}

1/ Each sub-indicator contributes 1/7 to total indicator.

Note: Abruzzo - ABR; Basilicata - BAS; Calabria - CAL; Campania - CAM; Emilia - Romagna ER; Friuli - Venezia Giulia - FVG; Lazio - LAZ; Liguria - LIG; Lombardia - LOM; Marche - MAR; Molise - MOL; Piemonte - PIE; Puglia - PUG; Sardegna - SAR; Sicilia - SIC; Toscana - TOS; Trentino - Alto Adige - TAA; Umbria - UMB; Valle D'Aosta - VDA; Veneto - VEN.

The computed sub-indicators suggest large differences in public services provision performance across regions. Regions with the highest values for sub-indicators include Friuli - Venezia Giulia (water provision, and electricity provision), Toscana (waste collection), Liguria (public transports and railway utilisation), Puglia (motorway network), and Lombardia (gas provision). Regions such as Friuli - Venezia Giulia, Liguria, Piemonte, Lombardia, Puglia, Emilia-Romagna, and Veneto report high TRPI indicators.

The derived TRPI will be used ahead in the next sub-section as our chosen output measure for the DEA analysis. 


\section{2 - DEA inputs}

We use two input measures: a financial measure, $X 1$, which is the overall per capita spending in the region, and a quantitative measure, $X 2$, the number of civil servants employed in each region defined as follows (data and sources are again reported in the Annex):

$X 1$ - total spending in the region/inhabitants in the region;

$X 2$ - civil servants per 1000 inhabitants = (civil servants/inhabitants $)^{*} 1000$.

We first use a one input (regional spending per capita) and one output (TRPI) model. Afterwards we expand the analysis to a two-input (regional spending and civil servants) and one output (TRPI) model. Since the number of DMUs is not that large, one has to be careful in not using too many inputs or outputs, which would then increase the number of efficient by default DMUs. ${ }^{12}$

\section{3 - DEA analysis and results}

The general relationship for the theoretical production possibility frontier that we expect to test, regarding efficiency in regional provision on public services, can be given by the following function for region $i$ :

$$
Y_{i}=f\left(X 1_{i}, X 2_{i}\right), i=1, \ldots, n
$$

where $Y_{i}$ is the TRPI, and $X 1_{i}$ and $X 2_{i}$ are the previously defined two inputs for each region.

In Table 4 we report the DEA analysis results obtained with the one input, $X 1$, and one output, TRPI, for the 20 Italian regions, both in terms of input and output oriented efficiency scores for 2001.

\footnotetext{
${ }^{12}$ With less than three DMUs per input and output there is the risk that too many DMUs will turn out to be efficient.
} 
Table 4. DEA results for Italian regions, 2001, 1 input (expenditure) and 1 output (TRPI)

\begin{tabular}{|c|c|c|c|c|c|c|}
\hline \multirow[t]{2}{*}{ Region } & \multicolumn{2}{|c|}{ Input oriented } & \multicolumn{2}{|c|}{ Output oriented } & \multirow{2}{*}{$\begin{array}{c}\text { Peers } \\
\text { Input/output }\end{array}$} & \multirow[t]{2}{*}{ CRS TE } \\
\hline & VRS TE & Rank & VRS TE & Rank & & \\
\hline Abruzzo & 0.879 & 6 & 0.605 & 14 & $\begin{array}{c}\text { Emilia - Romagna/ } \\
\text { Piemonte, Emilia - Romagna } \\
\text { Emilia - Romagna/ }\end{array}$ & 0.604 \\
\hline Basilicata & 0.482 & 12 & 0.488 & 16 & $\begin{array}{c}\text { Friuli - Venezia Giulia, Piemonte } \\
\text { Emilia - Romagna/ }\end{array}$ & 0.272 \\
\hline Calabria & 0.462 & 14 & 0.433 & 18 & Friuli - Venezia Giulia, Piemonte & 0.232 \\
\hline Campania & 0.330 & 18 & 0.633 & 12 & Emilia - Romagna/Friuli - Venezia Giulia & 0.244 \\
\hline Emilia - Romagna & 1.000 & 1 & 1.000 & 1 & Emilia - Romagna/Emilia - Romagna & 0.883 \\
\hline Friuli - Venezia Giulia & 1.000 & 1 & 1.000 & 1 & $\begin{array}{l}\text { Friuli - Venezia Giulia/ } \\
\text { Friuli - Venezia Giulia } \\
\text { Emilia - Romagna/ }\end{array}$ & 0.423 \\
\hline Lazio & 0.462 & 15 & 0.738 & 8 & $\begin{array}{l}\text { Friuli - Venezia Giulia, Piemonte } \\
\text { Friuli - Venezia Giulia, Piemonte/ }\end{array}$ & 0.394 \\
\hline Liguria & 0.588 & 11 & 0.984 & 4 & $\begin{array}{l}\text { Friuli - Venezia Giulia, Piemonte } \\
\text { Emilia - Romagna, Piemonte/ }\end{array}$ & 0.436 \\
\hline Lombardia & 0.882 & 5 & 0.893 & 6 & $\begin{array}{c}\text { Friuli - Venezia Giulia, Piemonte } \\
\text { Emilia - Romagna/ }\end{array}$ & 0.837 \\
\hline Marche & 0.688 & 8 & 0.710 & 9 & Friuli - Venezia Giulia, Piemonte & 0.559 \\
\hline Molise & 0.360 & 16 & 0.474 & 17 & Emilia - Romagna/Friuli - Venezia Giulia & 0.199 \\
\hline Piemonte & 1.000 & 1 & 1.000 & 1 & Piemonte/Piemonte & 1.000 \\
\hline Puglia & 0.825 & 7 & 0.828 & 7 & Friuli - Venezia Giulia, Piemonte & 0.754 \\
\hline Sardegna & 0.350 & 17 & 0.363 & 20 & Emilia - Romagna/Friuli - Venezia Giulia & 0.148 \\
\hline Sicilia & 0.465 & 13 & 0.417 & 19 & $\begin{array}{l}\text { Emilia - Romagna/ } \\
\text { Friuli - Venezia Giulia, Piemonte }\end{array}$ & 0.225 \\
\hline Toscana & 0.673 & 9 & 0.668 & 10 & $\begin{array}{c}\text { Emilia - Romagna/ } \\
\text { Friuli - Venezia Giulia, Piemonte }\end{array}$ & 0.515 \\
\hline Trentino - Alto Adige & 0.080 & 19 & 0.634 & 11 & $\begin{array}{c}\text { Emilia - Romagna/Friuli - Venezia Giulia } \\
\text { Emilia - Romagna/ }\end{array}$ & 0.059 \\
\hline Umbria & 0.600 & 10 & 0.618 & 13 & Friuli - Venezia Giulia, Piemonte & 0.426 \\
\hline Valle D'Aosta & 0.064 & 20 & 0.524 & 15 & Emilia - Romagna/Friuli - Venezia Giulia & 0.039 \\
\hline Veneto & 0.966 & 4 & 0.930 & 5 & Emilia - Romagna/Emilia - Romagna & 0.852 \\
\hline Average & 0.608 & & 0.697 & & & 0.455 \\
\hline
\end{tabular}

Notes: CRS TE - constant returns to scale technical efficiency. VRS TE - variable returns to scale technical efficiency.

From the results it is possible to see that three regions would labelled as most efficient and located on the theoretical production frontier: Emilia - Romagna, Friuli - Venezia Giulia, and Piemonte. Interestingly, these are all regions from the north of Italy, as is also the case of the regions ranked fourth and fifth, respectively Veneto and Lombardia. One should also mention that there is no DMU that is efficient by default, in other words all DMUs on the frontier are at least once a peer of a non-efficient region.

According to the average efficiency scores, there seems to scope for an improvement of around 39 per cent and 30 per cent respectively in terms of input efficiency and of output efficiency. 
In a different specification, we added the number of civil servants per 1000 inhabitants as a second input in other words we include $X 2$ in the production function (2). Table 5 reports this new set of results.

Table 5. DEA results for Italian regions, 2001, 2 inputs (expenditure, civil servants) and 1 output (TRPI)

\begin{tabular}{|c|c|c|c|c|c|c|}
\hline \multirow[t]{2}{*}{ Region } & \multicolumn{2}{|c|}{ Input oriented } & \multicolumn{2}{|c|}{ Output oriented } & \multirow{2}{*}{$\begin{array}{c}\text { Peers } \\
\text { Input/output }\end{array}$} & \multirow[t]{2}{*}{ CRS TE } \\
\hline & VRS TE & Rank & VRS TE & Rank & & \\
\hline Abruzzo & 0.942 & 8 & 0.605 & 14 & $\begin{array}{c}\text { Puglia, Veneto/ } \\
\text { Piemonte, Emilia - Romagna }\end{array}$ & 0.604 \\
\hline Basilicata & 0.884 & 9 & 0.538 & 15 & Puglia/Piemonte, Puglia & 0.528 \\
\hline Calabria & 0.770 & 14 & 0.439 & 18 & Puglia/ Friuli - Venezia Giulia, Piemonte & 0.409 \\
\hline Campania & 0.870 & 11 & 0.696 & 10 & Puglia/ Piemonte, Puglia & 0.681 \\
\hline Emilia - Romagna & 1.000 & 1 & 1.000 & 1 & Emilia - Romagna/Emilia - Romagna & 0.883 \\
\hline Friuli - Venezia Giulia & 1.000 & 1 & 1.000 & 1 & $\begin{array}{l}\text { Friuli - Venezia Giulia/ } \\
\text { Friuli - Venezia Giulia }\end{array}$ & 0.705 \\
\hline Lazio & 0.884 & 10 & 0.815 & 8 & Puglia/ Piemonte, Puglia & 0.800 \\
\hline Liguria & 0.954 & 7 & 0.997 & 6 & $\begin{array}{c}\text { Friuli - Venezia Giulia, Piemonte/ } \\
\text { Friuli - Venezia Giulia, Piemonte } \\
\text { Puglia, Piemonte, Veneto/ }\end{array}$ & 0.844 \\
\hline Lombardia & 0.978 & 6 & 0.965 & 7 & $\begin{array}{l}\text { Piemonte, Puglia } \\
\text { Puglia, Piemonte/ }\end{array}$ & 0.963 \\
\hline Marche & 0.808 & 12 & 0.710 & 9 & Friuli - Venezia Giulia, Piemonte & 0.651 \\
\hline Molise & 0.735 & 16 & 0.483 & 17 & Puglia/ Friuli - Venezia Giulia, Piemonte & 0.431 \\
\hline Piemonte & 1.000 & 1 & 1.000 & 1 & Piemonte/Piemonte & 1.000 \\
\hline Puglia & 1.000 & 1 & 1.000 & 1 & Puglia/Puglia & 1.000 \\
\hline Sardegna & 0.644 & 18 & 0.366 & 20 & Puglia/ Friuli - Venezia Giulia, Piemonte & 0.289 \\
\hline Sicilia & 0.750 & 15 & 0.422 & 19 & Puglia/Friuli - Venezia Giulia, Piemonte & 0.383 \\
\hline Toscana & 0.801 & 13 & 0.669 & 11 & $\begin{array}{c}\text { Puglia, Veneto/ } \\
\text { Friuli - Venezia Giulia, Piemonte }\end{array}$ & 0.616 \\
\hline Trentino - Alto Adige & 0.253 & 19 & 0.634 & 12 & $\begin{array}{c}\text { Puglia/ Friuli - Venezia Giulia } \\
\text { Puglia, Veneto/ }\end{array}$ & 0.198 \\
\hline Umbria & 0.715 & 17 & 0.618 & 13 & Friuli - Venezia Giulia, Piemonte & 0.510 \\
\hline Valle D'Aosta & 0.215 & 20 & 0.524 & 16 & Puglia/ Friuli - Venezia Giulia & 0.139 \\
\hline Veneto & 1.000 & 1 & 1.000 & 1 & Veneto/Veneto & 0.852 \\
\hline Average & 0.810 & & 0.724 & & & 0.624 \\
\hline
\end{tabular}

Notes: CRS TE - constant returns to scale technical efficiency. VRS TE - variable returns to scale technical efficiency.

From this new set of results now five regions are seen as most efficient: Emilia Romagna, Friuli - Venezia Giulia, and Piemonte, as before, plus Puglia and Veneto. In addition, Veneto is now efficient by default in the output oriented DEA analysis. Moreover, with this alternative specification using two inputs, on average the same level of outputs might be obtained with 19 per cent less resources. On the other hand, regions might have able to increase their outputs by 28 per cent using the same resources. 
Figure 5 provides an alternative presentation of the ranking of the regions' efficiency scores from Table 5 for the input oriented analysis. Again, all the efficient regions are located in the north of Italy, the exception being Puglia. This last region, already well ranked in the one input analysis (seventh place) is now labelled efficient because it has the lowest ratio of civil servants per 1000 inhabitants in the sample.

Figure 5 - Ranking of efficiency scores for the Italian regions, 2001 (DEA input oriented, 2 inputs, 1 output)

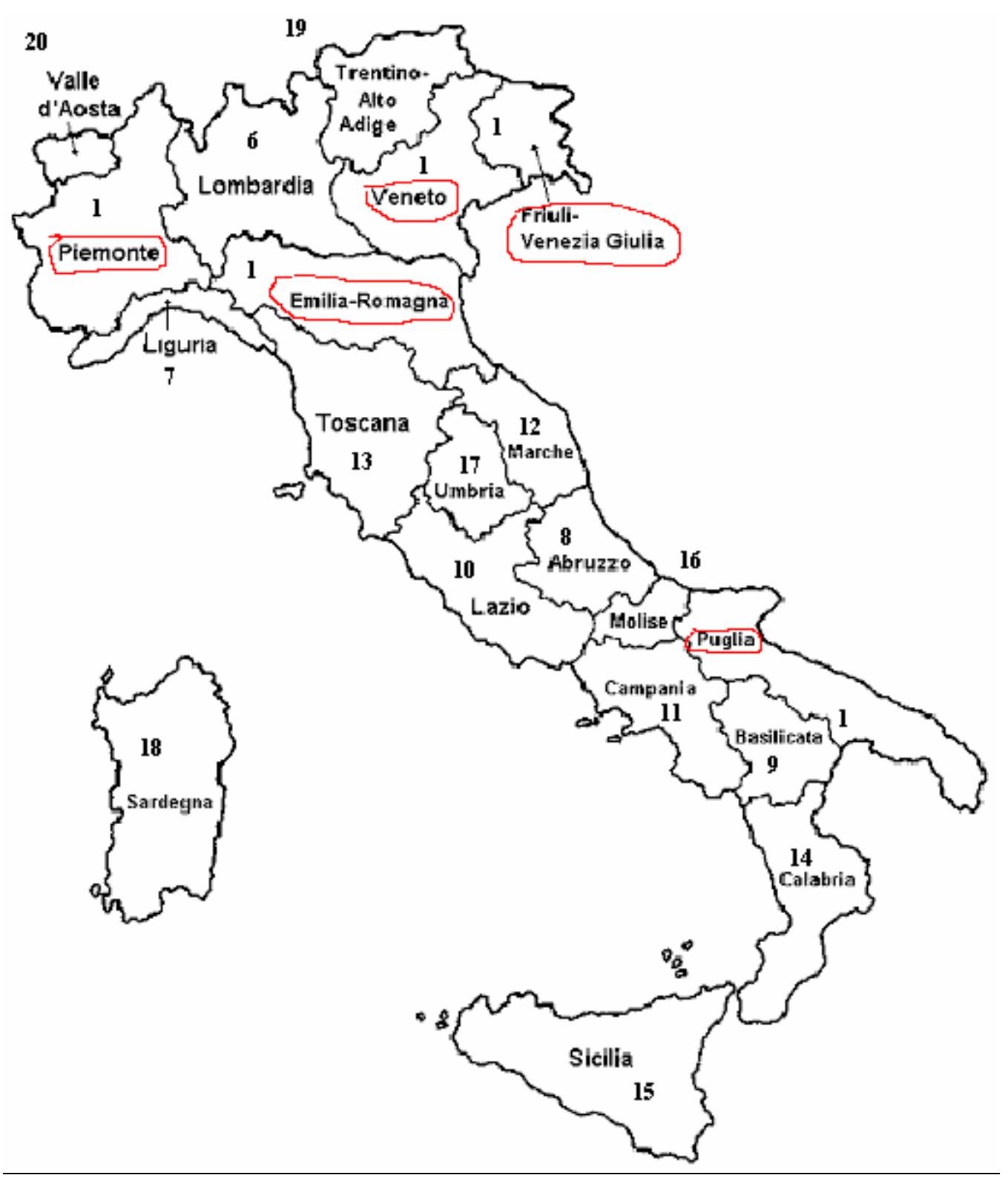


Notice however, that it is not easy to accurately identify the effects of regional spending on public services outcomes and separate the impact of spending from other influences. For instance, it is difficult to assess to what extent does irregularity in water provision and electricity service failures reflect public intervention rather than other factors such as climate, and geographical conditions. On that line of reasoning, adverse geographical conditions may also impair on the quality and cost of a regional communications infrastructure.

\section{5 - Conclusion}

In this paper, we have evaluated efficiency in providing public services across Italian regions by assessing a so-called TRPI index, our output measure, against the inputs used: regional per capita spending and the number of regional civil servants per 1000 inhabitants. With data for 2001, we constructed the performance index as a composite index of seven sub-indicators of regional public performance: water provision, waste collection, frequency of the accidental long interruptions of the electrical service, public transportation utilization, railway utilization, motorway network, and houses provide with gas.

Input and output efficiency scores were then estimated by solving a standard DEA problem with the 20 Italian regions as DMUs. The results that inefficiencies may be significant and some improvements may be possible across regions. On average, and using the results from the one output and two input analysis, regions could have increased their output by 28 percent using the same resources (as can be seen from the average output score from Table 5), with a region like Sardegna having a theoretical margin for potential output improvement of 63 percent. On the other hand, on average, regions could have decreased their inputs by 19 percent and still obtain the same output, with a region like Valle D'Aosta displaying scope for a potential improvement of 78 percent.

To our knowledge, this is the first attempt at computing a performance composite indicator for public services provision at the Italian regional level. This same is true for the subsequent non-parametric efficiency analysis. However, all these first results have to be seen as indicative and need to be interpreted with great care. Indeed, and 
for instance, it would be useful to use only the number of civil servants that are more directly involved in the provision of regional public services. This additional analysis may be pursued in future work if and when such data limitations can be overcome.

\section{Appendix}

\section{Table A1 - Main interventions that occurred in some public utilities sectors:} water and waste

\begin{tabular}{|c|c|c|}
\hline Industry & Regulatory Framework & Regulatory Governance \\
\hline $\begin{array}{l}\text { Water supply } \\
\text { and waste } \\
\text { water } \\
\text { management }\end{array}$ & $\begin{array}{l}\text { Law 36/94, (so called Galli Law) has } \\
\text { aimed to introduce competition within } \\
\text { water service sector in order to ensure } \\
\text { efficiency in production and management } \\
\text { of the resource. }\end{array}$ & $\begin{array}{l}\text { The Law has established new local water authorities } \\
\text { Autorità d'ambito Territoriale Ottimale (ATOs) and a } \\
\text { separation between water resource planning and the } \\
\text { operation of water utilities. } \\
\text { ATOs, whose borders are set by the Italian Regions, have } \\
\text { the task of } \\
\text {-defining the resource planning; } \\
\text {-assigning the operation to a private provider, selected } \\
\text { through auction; } \\
\text {-setting the price (tariff) cap for the water utilities } \\
\text { (including aqueduct systems, sewage systems and } \\
\text { treatment plants); } \\
\text {-drawing up the Piano d'Ambito (a } 30 \text { year plan) which } \\
\text { includes the timing and level of infrastructure investments, } \\
\text { and ensures that the provider respects the contract } \\
\text { requirements. }\end{array}$ \\
\hline
\end{tabular}

Waste $\quad$ EU Directive 91/156/CE

management EU Directive 91/689/CE

EU Directive 94/62/CE

Legislative Decree 22/1997 (so called Ronchi Decree)

Legislative Decree 389/1998

Law 426/1998

Law 326/2004
This group of legislative interventions covers collection, treatment and disposal of waste. It has introduced through several steps an increasing process of decentralisation of competences from the State to the Regions and the others local entities.

The regulatory governance is based on the definition of the integrated management of waste through regional and provincial plans.

The ATOs have the task to ensure the operation and the management of the waste according to the plans and in collaboration with the Regions, Provinces and Municipalities

The law has introduced the tariff mechanism to cover the operational costs, which should have replaced the TaRSU, a specific tax on waste, but by law the transition period was prorogated from Jannuary 1999 to jannuary 2005.

Source: Elaboration on OECD (2001) and Confservizi (2004). 

Table A2 - Main interventions that occurred in some public utilities sectors:
energy sector

\begin{tabular}{|c|c|c|}
\hline Industry & Regulatory Framework & Regulatory Governance \\
\hline \multirow[t]{2}{*}{-Electric power } & $\begin{array}{l}\text { Law } 481 / 95 \text { established the Authority for } \\
\text { Electricity and Gas (AEEG), }\end{array}$ & $\begin{array}{l}\text { There is an Independent National Authority called } \\
\text { Authority for Electricity and Gas (AEEG), created in } \\
\text { 1997. It has regulatory powers such as the determination } \\
\text { of } i \text { pricing; ii) quality level of services i, iii) economical } \\
\text { and technical conditions of the network access and } \\
\text { interconnession. }\end{array}$ \\
\hline & $\begin{array}{l}\text { EU Directive 96/92/CE } \\
\text { Legislative Decree (so called Bersani } \\
\text { Decree) 79/1999 liberalised the sector, } \\
\text { promoting competition into generation and } \\
\text { provision to liberalised customers }\end{array}$ & $\begin{array}{l}\text { The production, import/export and distribution are } \\
\text { liberalised } \\
\text { The transmission network is still public and managed by } \\
\text { the State through the Trasmission System Operator } \\
\text { (Gestore della Rete di Trasmissione), which has a } \\
\text { concession contract, with the owner Terma Spa, a } \\
\text { company of the Enel Group, the former monopolist public } \\
\text { provider, transformed in a joint-stock company in } 1999 \text {. } \\
\text { The Operator is obliged to connect to the network all the } \\
\text { requiring providers, which have to pay a fee determinated } \\
\text { by the AEEG. The market is divided in two: one part is } \\
\text { captive and the other free. In the first case the providers } \\
\text { pay a fee determinated by the AEEG and in the second a } \\
\text { price determinated by the market. } \\
\text { In addition, the reform allows for only one concession for } \\
\text { distribution on the territory of each municipality } \\
\text { The Operator has created the so called Single Buyer } \\
\text { (Acquirente Unico) and the Electric Market Manager } \\
\text { (Gestore Mercato elettrico). The former is encharged to } \\
\text { sell the energy to those providers operating in the captive } \\
\text { market. The tariffs are in this case regulated by AEEG.The } \\
\text { latter has the task to regulate the generation market, } \\
\text { ensuring the matching between demand and supply in } \\
\text { acompetitive framework. In this case the price is } \\
\text { determinated within the market. } \\
\text { The principle of uniform tariff is now applied only for } \\
\text { captive consumers. }\end{array}$ \\
\hline -Natural Gas & $\begin{array}{l}\text { EU Directive } 98 / 30 / \mathrm{CE} \\
\text { Delegated legislative Decreee } 625 / 96 \\
\text { eliminated the legal monopoly of ENI, the } \\
\text { public monopolist } \\
\text { Delegate Legislative Decree } 164 / 2000 \text { (so } \\
\text { called Letta Decree) }\end{array}$ & $\begin{array}{l}\text { Starting from } 2003 \text { small customers and household are } \\
\text { free to choose the providers, which cannot exceed a } \\
\text { ceiling of } 75 \% \text { of total imports and production (decreasing } \\
\text { by } 2 \% \text { a year, down to a } 61 \% \text { ceiling in 2010) nor to } \\
\text { exceed a ceiling of } 50 \% \text { of the sales to final consumers. } \\
\text { Both ceilings will be removed in } 2010 \text {. The AEEG has the } \\
\text { task to regulate Third Party Access to the storage, } \\
\text { transmission and distribution networks. It fixes the tariffs } \\
\text { for transmission, distribution and the captive customers } \\
\text { (Decision } 138 / 03 \text { ). on the basis of price caps. Concessions } \\
\text { for distribution are managed by the Municipalities through } \\
\text { auctions }\end{array}$ \\
\hline
\end{tabular}

Source: Elaboration on OECD (2001) and Confservizi (2004). 


\section{Table A3 - Main interventions that occurred in some public utilities sectors:}

transports sector

\begin{tabular}{|c|c|c|}
\hline Industry & Regulatory Framework & Regulatory Governance \\
\hline $\begin{array}{l}\text {-Railway } \\
\text { Sector }\end{array}$ & $\begin{array}{l}\text { EU Directive 95/18/CE } \\
\text { EU Directive 95/19/CE } \\
\text { President of the Republic Decree-Dpr } \\
277 / 1998 \text {, introduced the access to } \\
\text { international operators and the accounting } \\
\text { separation } \\
\text { President of the Republic Decree-Dpr } \\
146 / 1999 \text { implemented the criteria for } \\
\text { licencing and allocation of infrastructure } \\
\text { capacity } \\
\text { Law 326/2004 }\end{array}$ & $\begin{array}{l}\text { In } 1992 \text { Ferrovie dello Stato, the former monopolist } \\
\text { became a joint stock company, still owned by the Ministry } \\
\text { of Treasury. } \\
\text { The legal separation between the network operator (RTF) } \\
\text { and the service company (Trenitalia) took place in 2000, } \\
\text { after the inroduction of the accounting separation in } 1999 \text {. } \\
\text { The State responsabilities for local railways have been } \\
\text { decentralised to the regions. Competition for local should } \\
\text { have been introduced in 2003, but the Budget Law of } 2004 \\
\text { has prorogated the transition period, for the local public } \\
\text { services } \\
\text { The international freeight segment has been liberlised } \\
\text { during } 2000 \text { (licens has been granted. All other segments } \\
\text { have been liberalised with the Budget Law of } 2000 \text { and } 4 \\
\text { licences already issued for the international segment have } \\
\text { been extended. In October } 2000 \text { the network operator has } \\
\text { adopted a Network code for non-discriminatory access }\end{array}$ \\
\hline
\end{tabular}

$\begin{array}{ll}\text {-Transports on } & \text { CIPE Decision n.319/1996 } \\ \text { roads } & \text { IT Directive } 1998 \text { (so called Ciampi-Costa } \\ & \text { Directive) } \\ & \text { Legislative Decree 400/1999 } \\ & \text { Law 448/2001 } \\ & \text { Law 326/2004 }\end{array}$

The road network is still public and managed by the State through the ANAS, which has a concession contract, with the different companies and the former main operator Società Autostrade transformed in a joint-stock company and privatised.

ANAS has to define the parameters, which each company needs in order to determinate the price cup and consequently the tariff or toll.

The Legislative Decree 400/1999 has

-given a new definition of subsidy transfer mechanisms for minimum services by the Regional Governments;

-introduced the adoption of service contracts to regulate the relationship between the granting Authority and the service provider;

-affirmed the compulsory public tenders for the assignment of services by the end of 2003;

Additionally all the special companies and consortia should have been transformed into joint stock companies or cooperatives (within 31st December 2000);

Eeach Regional Government had to established a regional fund for transport replacing the old national transportation fund.

The Budget Law of 2004 has prorogated the transition period, for the local public services and pushed towards the adpotion of the "in house" provision, stopping the liberation process, which was confirmed in the Budget Law of 2001

Source: Elaboration on OECD (2001) and Confservizi (2004). 


\section{References}

Afonso, A. and Fernandes, S. (2003). "Efficiency of local Government Spending: Evidence for the Lisbon Region,” WP 09/2003/DE/CISEP, ISEG/UTL - Technical University of Lisbon

Afonso, A.; Schuknecht, L. and Tanzi, V. (2003). "Public Sector Efficiency: An International Comparison,” ECB Working Paper n 242, July, forthcoming in Public Choice.

Afonso, A. and St. Aubyn, M. (2004). "Non-parametric Approaches to Public Education and Health Efficiency in OECD Countries," ISEG-UTL, Working Paper $n^{\circ}$ 1/2004/DE/CISEP/UECE, forthcoming in the Journal of Applied Economics.

Balassone, F.; Francese, M. and Giordano, R. (2002). "Efficienza nei servizi pubblici: una rassegna della letteratura," in L'efficienza nei servizi pubblici, Banca d'Italia, Roma.

Boitani, A. and Cambini, C. (2001). "La riforma del trasporto pubblico locale in Italia: problemi e prospettive,” Hermes - Working Paper 5, 2001.

Charnes, A.; Cooper, W. and Rhodes, E. (1978). "Measuring the efficiency of decision making units,” European Journal of Operational Research, 2 (6), 429-444.

Clements, B. (2002). "How Efficient is Education Spending in Europe?” European Review of Economics and Finance, 1(1), 3-26.

Coelli, T., Rao, D. and Battese, G. (2002). An Introduction to Efficiency and Productivity Analysis, sixth edition, Massachusetts, Kluwer Academic Publishers.

Confservizi (2004). "Servizi Pubblici, sviluppo regolazione, compatibilità sociale e ambientale. Rapporto Confservizi sui Servizi Pubblici Locali 2004,” quaderni n. $5 / 2004$

De Borger, B. and Kerstens, K. (1996). "Cost Efficiency of Belgian Local Governments: A Comparative Analysis of FDH, DEA, and Econometric Approaches”, Regional Science and Urban Economics, 26(2), 145-170.

Fakin, B. and de Crombrugghe, A. (1997). "Fiscal Adjustment in Transition Economies: Social Transfers and the Efficiency of Public Spending, a Comparison with OECD Countries”, Policy Research Working Paper 1803, Washington, The World Bank.

Farrell, M. (1957). "The Measurement of Productive Efficiency,” Journal of the Royal Statistical Society, serie A, General, 120, 253-81.

Giarda, P. (2004). "Decentralization and intergovernmental fiscal relations in Italy: a review of past and recent trends,” mimeo.

Gupta, S. and Verhoeven, M. (2001). "The Efficiency of Government Expenditure Experiences from Africa”, Journal of Policy Modelling, 23, 433-467. 
Istat (2001). I servizi pubblici e di pubblica utilità: utilizzo e soddisfazione, Roma.

OECD (2001). Regulatory reform in Italy, Paris, OECD Reviews of Regulatory Reform, April.

Scaglioni, C. (2004). “The Local Agencies for the Public Services. The Italian case,” in Proceedings of the $6^{\text {th }}$ European Evaluation Society Biennial Conference, Governance, Democracy and Evaluation, Berlin, September 30- October 2, 2004.

St. Aubyn, M. (2003). "Evaluating Efficiency in the Portuguese Education Sector", Economia, 26, 25-51.

Thanassoulis, E. (2001). Introduction to the Theory and Application of Data Envelopment Analysis, Kluwer Academic Publishers. 


\section{Annex - Data and Sources}

Table 1 - Original data set for the TRPI (2001)

\begin{tabular}{|c|c|c|c|c|c|c|c|}
\hline \multirow{3}{*}{ Region } & \multirow[b]{2}{*}{$\begin{array}{l}\text { Irregularity } \\
\text { in the water } \\
\text { provision }\end{array}$} & \multirow{2}{*}{$\begin{array}{l}\text { Solid waste } \\
\text { collection, } \\
\text { kg per } \\
\text { Inhabitants }\end{array}$} & \multirow{2}{*}{$\begin{array}{l}\text { Frequency of } \\
\text { occidental } \\
\text { long } \\
\text { interruptions } \\
\text { of electrical } \\
\text { service }\end{array}$} & \multicolumn{2}{|c|}{$\begin{array}{l}\text { Public services users over } \\
\text { total users, moving for } \\
\text { work reasons (\%) } \\
\end{array}$} & \multirow[b]{2}{*}{$\begin{array}{l}\text { Motorway } \\
\text { network } \\
(\mathrm{km})\end{array}$} & \multirow{2}{*}{$\begin{array}{l}\text { Houses } \\
\text { provided } \\
\text { with gas } \\
\text { (thousands) }\end{array}$} \\
\hline & & & & $\begin{array}{l}\text { Public } \\
\text { transport } \\
\text { utilization } \\
\text { index }\end{array}$ & $\begin{array}{c}\text { Railway } \\
\text { utilization } \\
\text { index }\end{array}$ & & \\
\hline & $1 /$ & 2/ & $3 /$ & $1 / 3 /$ & $1 / 3 /$ & $4 /$ & $1 /$ \\
\hline Abruzzo & 21.8 & 540.9 & 3.37 & 26.7 & 2.6 & 7422 & 385 \\
\hline Basilicata & 28.2 & 485.3 & 4.91 & 30.5 & 1.8 & 4855 & 122 \\
\hline Calabria & 51.1 & 343.1 & 8.19 & 26.7 & 3.7 & 10147 & 224 \\
\hline Campania & 19.4 & 448.5 & 4.92 & 31.6 & 5.9 & 10239 & 1031 \\
\hline Emilia - Romagna & 5.9 & 589.3 & 2.18 & 17.6 & 3.8 & 10945 & 1489 \\
\hline Friuli - Venezia Giulia & 2.2 & 479.3 & 1.76 & 20.1 & 3.5 & 3593 & 401 \\
\hline Lazio & 13.9 & 520.3 & 4.14 & 35.7 & 6.6 & 9958 & 1754 \\
\hline Liguria & 5.3 & 523.8 & 2.46 & 36.2 & 11.7 & 4067 & 628 \\
\hline Lombardia & 7.9 & 507.9 & 1.82 & 29.9 & 6.5 & 11860 & 3346 \\
\hline Marche & 9.7 & 505.0 & 2.46 & 19.0 & 1.7 & 6831 & 422 \\
\hline Molise & 21.1 & 468.9 & 4.02 & 31.2 & 1.6 & 2839 & 91 \\
\hline Piemonte & 7.5 & 491.8 & 2.66 & 24.0 & 5.8 & 22636 & 1534 \\
\hline Puglia & 30.1 & 462.7 & 3.62 & 21.2 & 4.4 & 11630 & 913 \\
\hline Sardegna & 42.9 & 526.5 & 7.37 & 23.6 & 2.9 & 8543 & 10 \\
\hline Sicilia & 39.6 & 387.3 & 5.80 & 19.5 & 1.7 & 16339 & 636 \\
\hline Toscana & 11.5 & 664.0 & 3.30 & 19.1 & 4.3 & 11299 & 1186 \\
\hline Trentino - Alto Adige & 4.5 & 537.4 & 3.50 & 26.2 & 3.1 & 4554 & 143 \\
\hline Umbria & 12.9 & 657.3 & 2.26 & 18.3 & 3.2 & 4287 & 235 \\
\hline Valle D'Aosta & 9.4 & 637.4 & 1.80 & 12.7 & & 762 & 10 \\
\hline Veneto & 8.9 & 595.6 & 2.73 & 20.2 & 3.8 & 10097 & 1273 \\
\hline Average & 17.7 & 518.6 & 3.66 & 24.5 & 3.9 & 8645 & 792 \\
\hline Minimum & 2.2 & 343.1 & 1.8 & 12.7 & 1.6 & 762.0 & 10.0 \\
\hline Maximum & 51.1 & 664.0 & 8.2 & 36.2 & 11.7 & 22636.2 & 3346.0 \\
\hline
\end{tabular}

1/ Source: Istat, I servizi pubblici e di pubblica utilità: utilizzo e soddisfazione. Indagine Multiscopo sulle famiglie, “Aspetti della vita quotidiana”, 2001.

2/ Source: Istat - Statistical Yearbook, 2001-2002.

3/ Frequency of the accidental long interruptions of the electrical service (average number for customer). Source: Istat and MEF-DPS on data provide by the Autorità per l'energia elettrica e il gas. Indicatori di contesto, 2003.

4/ Regional data are calculated on the indication of DPCM from 21/09/2001, which identifies the regional network lenght. Source: Istat, Statistical Yearbook 2002 
Table 2 - Additional original data set (2001)

\begin{tabular}{|c|c|c|c|c|c|c|}
\hline Region & Population & $\begin{array}{c}\text { Civil } \\
\text { servants } \\
\text { (regional) }\end{array}$ & $\begin{array}{c}\text { Area } \\
\text { (square } \\
\text { km) } \\
1 /\end{array}$ & $\begin{array}{c}\text { Total } \\
\text { expenditure } \\
\text { per region } \\
\text { (million euro) } \\
\text { 3/ }\end{array}$ & $\begin{array}{c}\text { Expenditure } \\
\text { per capita } \\
\text { (euro) }\end{array}$ & $\begin{array}{c}\text { Civil } \\
\text { servants per } \\
1000 \\
\text { inhabitants }\end{array}$ \\
\hline Abruzzo & 1281283 & 18635 & 10763 & 174.9 & 137 & 14,5 \\
\hline Basilicata & 604807 & 7775 & 9995 & 150.5 & 249 & 12,9 \\
\hline Calabria & 2043288 & 30150 & 15081 & 530.6 & 260 & 14,8 \\
\hline Campania & 5782244 & 75774 & 13590 & 2103.1 & 364 & 13,1 \\
\hline Emilia - Romagna & 4008663 & 60831 & 22117 & 480.9 & 120 & 15,2 \\
\hline Friuli - Venezia Giulia & 1188594 & 23755 & 7858 & 393.9 & 331 & 20,0 \\
\hline Lazio & 5302302 & 68439 & 17236 & 1377.8 & 260 & 12,9 \\
\hline Liguria & 1621016 & 26559 & 5422 & 511.2 & 315 & 16,4 \\
\hline Lombardia & 9121714 & 118209 & 23863 & 1332.3 & 146 & 13,0 \\
\hline Marche & 1469195 & 22550 & 9694 & 256.3 & 174 & 15,3 \\
\hline Molise & 327177 & 5073 & 4438 & 108.9 & 333 & 15,5 \\
\hline Piemonte & 4289731 & 60975 & 25402 & 586.3 & 137 & 14,2 \\
\hline Puglia & 4086608 & 46537 & 19358 & 614.0 & 150 & 11,4 \\
\hline Sardegna & 1648044 & 29091 & 24090 & 565.2 & 343 & 17,7 \\
\hline Sicilia & 5076700 & 77039 & 25711 & 1308.5 & 258 & 15,2 \\
\hline Toscana & 3547604 & 54010 & 22994 & 632.1 & 178 & 15,2 \\
\hline Trentino - Alto Adige & 943123 & 42508 & 13607 & 1411.3 & 1496 & 45,1 \\
\hline Umbria & 840482 & 14300 & 8456 & 168.0 & 200 & 17,0 \\
\hline Valle D'Aosta & 120589 & 6395 & 3263 & 226.0 & 1874 & 53,0 \\
\hline Veneto & 4540853 & 64182 & 18399 & 564.2 & 124 & 14,1 \\
\hline Total & 57844017 & 852785 & 301336 & 13496.0 & & \\
\hline Average & 2892201 & 81218 & 15067 & 1285.3 & 372 & 18.3 \\
\hline Minimum & $\begin{array}{l}120589 \\
\text { (VDA) }\end{array}$ & $\begin{array}{c}5073 \\
(\mathrm{MOL})\end{array}$ & $\begin{array}{c}3263 \\
\text { (VDA) }\end{array}$ & $\begin{array}{c}108.9 \\
\text { (MOL) }\end{array}$ & $\begin{array}{c}120 \\
\text { (ER) }\end{array}$ & $\begin{array}{c}11.4 \\
\text { (PUG) }\end{array}$ \\
\hline Maximum & $\begin{array}{c}9121714 \\
(\mathrm{LOM})\end{array}$ & $\begin{array}{l}118209 \\
\text { (LOM) }\end{array}$ & $\begin{array}{l}25711 \\
\text { (SIC) }\end{array}$ & $\begin{array}{l}2103.1 \\
\text { (CAM) }\end{array}$ & $\begin{array}{c}1874 \\
\text { (VDA) }\end{array}$ & $\begin{array}{c}53.0 \\
\text { (VDA) }\end{array}$ \\
\hline
\end{tabular}

Note: Campania - CAM; Emilia - Romagna - ER; Lombardia - LOM; Molise - MOL; Puglia - PUG; Sicilia - SIC; Valle D'Aosta - VDA.

1/ Source: Istat, Statistical Yearbook 2002.

2/ Source: Statistiche delle Amministrazioni Pubbliche-ISTAT, 2002.

3/ Source: MEF-DPS, Banca Dati Conti Pubblici Terrritoriali, specific data compilation for the present work, http://www.dps.tesoro.it/cpt/banca_dati_home.asp. 